Alexandra Vivien Bakó

\title{
Capacity to handle complexity - The importance of contextual awareness in healthcare communication in English as a lingua franca
}

Bakó Alexandra Vivien: A komplexitás kezelésének képessége - A kontextus iránti tudatosság fontossága az egészségügyi kommunikációban az angolt mint lingua francát használva

\begin{abstract}
Összefoglaló
A magyar egészségügyi dolgozók - akárcsak kollégáik világszerte - amikor olyan külföldi páciensekkel kommunikálnak, akikkel nincs közös anyanyelvük, az esetek többségében az angolt mint lingua francát (ELF) használják. Ezek a kommunikációs szituációk komoly kihívást jelentenek az egészségügyi dolgozók számára, mivel rendelkezniük kell hozzá azzal a képességgel, hogy folyamatosan igazítsák nyelvhasználatukat a páciensek sajátjuktól eltérö kognitiv, nyelvi és kommunikatív-pragmatikai sémáihoz. Annak érdekében, hogy kifejlesszék ezt a képességüket, a szaknyelvi óráknak figyelniük kell az egészségtudományi hallgatók ELF kontextus iránti tudatosságának fejlesztésére, amely alapul szolgál terminológia használati döntéseikhez. Jelen kutatás az ELF kontextusok komplexitását és dinamikusságát kívánja bemutatni empirikus adatokkal alátámasztva, olyan egészségügyi dolgozókkal folytatott interjúk alapján, akiknek komoly nemzetközi munkatapasztalatuk van a külföldi betegekkel folytatott kommunikációban. A kutatás eredményei hozzájárulhatnak az angol szaknyelvi órák hatékonyságának fejlesztéséhez.
\end{abstract}

Kulcsszavak: egészségügyi kommunikáció, angol mint lingua franca (ELF), orvosi terminológia, interperszonális sémák, kontextus iránti tudatosság

\begin{abstract}
Hungarian healthcare providers - as most of their colleagues around the world - engage in interaction with foreign patients, whom they do not share a mother tongue with, in English as a lingua franca (ELF) most of the time. These communicative situations pose great challenges to healthcare providers, as they have to be capable of adjusting their language use to their patients' cognitive, linguistic and communicative-pragmatic schemata which often differ from their own. In order to develop such a capacity, ESP classes must focus on improving health science students' awareness in exploring various ELF contexts which form ground for making informed decisions on the use of terminology. The present research aims
\end{abstract}

at showing the complex dynamic nature of these ELF contexts based on empirical data collected via interviews with Hungarian healthcare providers who have extended experience in working with patients in international environments. The results can inform the everyday practice of ESP teachers in the field of the health sciences.

Key words: healthcare communication, English as a lingua franca (ELF), medical terminology, interpersonal schemata, contextual awareness

\section{INTRODUCTION}

Communication with patients is a challenging task for healthcare providers even if they share a mother tongue, as plenty of features must be 
attended to in order to ensure the highest level of efficiency possible in the given communicative situation. In the case of ELF (English as a lingua franca) communication, where there is a smaller amount of shared linguacultural background among healthcare providers and patients, the situation gets even more complex. In order to prepare health science students for these challenges, they have to be enabled to handle this complexity. Since it is impossible to predict all the future situations healthcare providers can find themselves, the aim of ESP (English for Specific Purposes) classes should be to raise health science students' awareness of the complex dynamic nature of communicative situations in ELF, and to improve their capacity to handle this complexity and adjust their language use accordingly. The first step to reach this aim is to show students how complex and relative those contextual features are which can influence their choices of terminology. The present paper wishes to explore these contextual features in communication with patients based on interview data with Hungarian healthcare providers who have worked with patients with various linguacultural backgrounds while using English as a medium in communication with them. It is assumed that the findings can add to the efficiency of ESP classes for healthcare purposes, as by raising students' awareness of the various features of ELF contexts, their language user autonomy could be improved.

\section{THEORETICAL BACKGROUND}

\subsection{The context of healthcare communication}

\subsubsection{Definition of context}

First of all, it must be explained what is meant by context. There have been various approaches to defining context with various points of emphasis as Widdowson (2004) demonstrates it. Fundamentally, certain theories of context focus more on the external features of context, such as the environment, objects, people etc., for example, Malinowski (1923) who suggests that meaning is context- dependent - or as Widdowson points out, it is implied that it is in fact "context-determined" (Widdowson 2004:38) - i.e. that the immediate surroundings of the communicative situation and the action or purpose the language is used for determines the meaning of an utterance. Similarly, Mey (1993) underlines that it is the surroundings that make language intelligible, although he also asserts that these external features are taken into consideration through the schemata of the interactants. Schemata in this sense are the elements of the concrete setting which "make the linguistic expressions of their [the interactants'] interaction intelligible" (Mey 1993:38). As Widdowson (2004) concludes, the theories above fail to realize that they in fact join the entirely abstract notion of grammar or language to the entirely concrete nature of the context. Firth (1957) is the first describing the notion of context of situation as an abstract psychological construct, which brings into relation the relevant features of the participants, as well as the relevant objects and the effect of verbal action that together make up the context. Furthermore he incorporates language into his theory, but fails to describe the interplay between language use and context. It is Hymes $(1968,1974)$ who emphasises that code (i.e. language) and context bilaterally act upon each other, and furthermore, he defines context as both scene - a socio-psychological construct and setting - the actual surroundings of the communication. In his theory scene is created based on the schematically relevant features of the situation, and meaning is created via mutual elimination of non-relevant meanings based on the interaction of code and context. However, as Illés (2012) points out, this theory is fundamentally analyst-oriented, where the researcher is to decide what is relevant in the given communicative situation. A theory, where the creation of context is assigned to the participants of the communication is Sperber and Wilson's Relevance Theory (1995), who define context as a set of assumptions, the contextual assumptions that are used for interpreting utterances. Still, as Widdowson 
(2004) argues, they fail to include that the conjunction of text and context must be in interaction in order for meaning to emerge. In other words, they imply that meaning is created based on unilateral inference, a covert cognitive procedure on the part of the hearer of the message, and fail to elaborate on the overt negotiation of meaning during interaction. Grice (1975) on the other hand, assumes a bilateral interaction among which meaning is created in the interpersonal schemata of the interlocutors. He gives answer to how meaning is created, as opposed to other theories which describe the features of the communicative situation based on what meaning comes into existence. He emphasises that interlocutors accommodate to the maxims of communication in reference to which they can decide what is relevant from their interpersonal schemata i.e. context of the situation. These are the maxims of quantity, quality, relation, and manner. The maxim of quantity suggests the interlocutors that they should "be as informative as is required (for the purposes of the exchange)" (Grice 1975:45). The maxim of quality requires from the participants of communication to make contributions that are true, which entails two things: 1 . not saying what is false, and 2 . not saying that for which one lacks adequate evidence. The third maxim, relation asks the participants to be relevant, and the last one, manner makes suggestions about how to say what is to be said. This includes "1. Avoid obscurity of expression; 2. Avoid ambiguity; 3. Be brief (avoid unnecessary prolixity); 4. Be orderly." As Grice concludes it "Be perspicuous." (Grice 1975:46). For example, when doctors want to decide how much information to share with the patient, they examine certain characteristics of the patient or of the whole situation - such as how fearful the patient is, or how much time they have for communication, and then can they choose the right amount of shared information in the manner they find the most appropriate in that situation. Obviously, there can be no rule for such "examinations", rather each and every situation is different, even the same doctor can decide on various solutions in a communicative situation with the same or a similar patient. Therefore the maxims are only reference points that lead one's choices on language use.

So far it can be concluded that context is an abstract schematic construct - the shared interpersonal socio-psychological schemata of the interlocutors acting as a filter for selecting the relevant components of the communicative situation based on the Gricean maxims (1975) which is in constant interaction with the code of language - the linguistic resources of the interlocutors. A schema, as Widdowson (2004) puts it, is "a cognitive construct, a configuration of knowledge which we project on to events as to bring them into alignment with familiar patterns of experience and belief (see Freedle 1977, de Beaugrande 1980, Widdowson 1983)". It is an aid that helps interlocutors "finding the way through the undefined mass of factors" of the context (Widdowson 2004:43). As Wilson and Sperber (1995) put it, schemata work as a set of contextual assumptions that help interpreting utterances. These assumptions are continuously formed in the interactive processes based on the already existing assumptions of the interlocutors. Thus, interpersonal schemata are in fact shared contextual assumptions. Furthermore, since the creation of meaning happens along such a continuous negotiation of the interlocutors, these schematic constructs are necessarily of a dynamic nature. Dynamism characterises any phenomenon where the components are in constant change, activity or progress. This is due to the action and interaction of forces within the components of the given phenomenon. In the case of communication and meaning formation, it has already been stated that code and context are in a constant interplay, furthermore, the contextual assumptions of the interlocutors are continuously adjusted to each other - making context dynamic per se. As Dörnyei (2014:81) defines dynamic systems, they must have "(a) at least two or more elements that are (b) interlinked with each other but which also (c) change independently over time". Furthermore, as most of dynamic systems, 
context is also a complex system according to Larsen-Freeman's (2012:205-206) description:

1) Complex systems are open and dynamic.

2) They operate under conditions that are not in equilibrium.

3) Complex systems are systems because they comprise many elements or agents, which interact.

4) Change/dynamism is central. The systems adapt both through interaction with the environment and through internal organisation/self-organisation.

5) The strength of interaction changes over time. Therefore, multiple routes are often possible between components, mediated in different ways.

6) The complexity of complex systems is emergent. It is not built into any one element or agent, but rather arises from their interaction.

7) Because the systems are open, what arises may be in nonlinear relation to its cause. In other words, an unexpected occurrence may take place at any time.

8) The structure of a complex system is maintained even though its components may change.

9) The environment in which they operate is part of a complex system.

10) Complex systems display behaviour over a range of timescales and at different levels of complexity - the latter are nested, one within another.

11) Complex systems sometimes display chaotic variation.

12) Complex systems iterate - they revisit the same territory again and again, which means that the present level of development is critically dependent on what preceded it.

However, it must be underlined that during communication not all of the elements, or in other words contextual features, of the complex dynamic system of context come into play with the same degree. Certain components are foregrounded based on what is perceived as relevant by the interlocutors. Relevancy is added to a contextual feature if it takes part or forms ground for achieving one's communicative aim.

Consequently, context is the abstract complex dynamic system of the shared sociopsychological schemata of the interlocutors, the features of which are highlighted based on what is perceived as relevant by the interlocutors in line with their communicative aim.

\subsubsection{Context in healthcare communication in English}

Hungarian healthcare providers - as most of their colleagues around the world - engage in interaction with foreign patients, whom they do not share a mother tongue with, in English most of the time. As experience shows (cf. Pilegaard 1997; Ruiz Rosendo 2008; Frînculescu 2009; Corrizzato \& Goracci 2013), in the vast majority of such communicative situations healthcare providers use English as a lingua franca in various international settings. Healthcare communication is a delicate matter even when the healthcare provider and the patient share their $L 1$, as in most cases the time to talk to a patient is very limited - especially in emergent cases, sensitive issues are handled, many times negative information has to be given to the patient, or simply the patient feels defenceless and at the mercy of the medical personnel (cf. Pilling 2011). In case English is the mediating language between the healthcare professional and the patient, "culturally and linguistically appropriate communicative competence is a key skill for medical professionals: it can literally be lifesaving" (Van de Poel et al. 2013:vii). In international settings, especially in ELF context, appropriateness - e.g., the level of formality, cannot be evaluated based on fixed conventions - or in other words 'norms' - of a specific discourse community, but it inevitably becomes relative to the given context of the communicative situation. As Seidlhofer (2011:18) explains, in ELF communication "the participants gauge a level of language at which they can operate, and settle on ad hoc, pro tem norms that are adequate to the task and 
commensurate to the command of the linguistic resources they have in common".

As it has already been pointed out, context is looked at as a mental construct, and therefore is only a set of assumptions in the head of the interlocutors. For healthcare providers to engage in efficient communication, it is their responsibility to make their language use appropriate in the given situation and therefore to ensure that their assumptions are based on the exploration of the context of the situation to the fullest. Apart from the general contextual features, such as the age, state, gender, or social background of the patient, amount of shared knowledge on the discussed medical condition, or the characteristics of the setting, they also have to be attentive to the cultural differences, the extent of shared social and cognitive schemata, as well as to the shared linguistic resources with the patient. Widdowson (2007) underlines that communication between speakers of ELF builds on a smaller amount of shared knowledge, than in the case of interaction of native speakers of English. He adds that this leads to an increased reliance on language, as more things have to be verbalized. However, in the case of healthcare communication, in many cases there is very little time to talk, depending on the patient's status or the general settings of health care in the given circumstances - e.g., a lot of patients need to be provided care in a short period of time. Accordingly, this leads to the case that the healthcare provider must be very conscious about what to say, what words to use, etc. Thus, to communicate efficiently, healthcare providers must pay attention to a great number of contextual features while talking to patients. In other words, they need to have a high level of contextual awareness, which will be elaborated in the next section.

\subsubsection{Contextual awareness}

Although the context of a communicative situation involving healthcare providers and patients shows a very complicated picture with a large number of contextual features, it must be re-emphasised that from all the possible features healthcare providers will be attentive to only those that they consider relevant in the given situation. However, in order to enhance the efficiency of communication, healthcare providers must be prepared to function with higher levels of contextual awareness in ELF contexts, as no protocol can be set for handling each and every situation. Accordingly, they must be trained for awareness on how to capture the complexity of the issue, for sensitivity to attend to the various contextual features, and for strategies to decide on the relevant features.

Due to context being a complex dynamic system per se, healthcare providers when finding ways to achieve their communicative aim must engage in a continuous problemsolving activity, as they can never have the relevant knowledge to an immediate solution, and have to perform deliberate and controlled processes to reach their purpose (cf. Eysenck 2012:309). Such problem-solving attitude focuses on the processes of communication, which involves a continuous other-monitoring on behalf of the healthcare provider as well. In other words, healthcare providers must explore the relevant contextual features in the given communicative situation that form basis for and influence their decision-making as for their language use. In line with this, it is a must for them to be able to activate the necessary strategies to come to efficient solutions in order to reach their communicative aim. Such an ability is not the same as communicative competence - i.e. a collection of knowledge to draw on while trying to communicate, rather a capacity "to exploit this knowledge to achieve particular communicative purposes" (Widdowson 1983:34). More explicitly, in the case of healthcare providers, it is not enough to have an extended lexis containing various denominations of healthcare concepts and know how formal a denomination is in the native speaker environment of the target language, or explore the various sociocultural backgrounds of patients. What is important is that they are actually capable of shaping their language use by drawing on these sources.

Therefore, the aim of an ESP class should be to develop such a capacity of health science 
students, so that they can successfully engage in any communicative situation with patients where they need to use English as the mediating language. In other words, it is in the possession of such a problem solving capacity that healthcare providers can become autonomous language users. In the upcoming sections, it will be elaborated how such autonomy can be achieved within the borders of an ESP classroom by focussing on how contextual features can influence one's language use.

\subsection{Terminological awareness as part of contextual awareness}

The scope of an ESP classroom and accordingly the scope of the present research allow focussing only on a segment of the complex phenomenon of contextual awareness, and it is how contextual awareness influences the language use, more specifically the use of medical terminology in communication with patients. This capacity is called terminological awareness - the exploitation of medical terminology in line with a raised contextual awareness to enhance the efficiency of communication with patients in ELF.

Fundamentally, terminological awareness is a capacity, a device for choosing medical terms according to the relevant features of the context of the communicative situation. When healthcare providers enter communication with patients, they explore their characteristics and shared schemata - i.e. interpersonal schemata. It is based on these assumptions of healthcare providers that they formulate their utterances, which then they evaluate on the basis of the perlocutionary effect on the patient - i.e. how much the patient has understood from the healthcare provider's utterance. In the case of healthcare communication, the choice of terminology is a very important issue, as a lot of concepts have to be denominated with terms that patients might not be familiar with, or the healthcare provider must find the denomination for a concept the patient is familiar with. The capacity to decide which terms to use is based on the efficient exploration and exploitation of the contextual features of the given communicative situation (Figure 1). This procedure happens continuously while communicating with the patient, and the language produced is constantly adjusted to the shared cognitive, linguistic and sociocultural schemata of the interlocutors.



Figure 1 The application of terminological awareness

Recent theories of terminology (Cabré 2003; Faber 2012; Fóris 2012, 2013) claim that terminological units contain three main components: the linguistic, the cognitive, and the communicative-pragmatic. They argue that the meaning of a terminological unit is based on what is activated in the language user's mind by the uttered term on these three fields. In other words, the perlocutionary effect of an utterance in healthcare communication is heavily influenced by the values each medical term carries for the patient. As it was mentioned above, it is the healthcare provider's responsibility to make sure that patients interpret the message as it is intended by the professional, and therefore understand all the things that are relevant for them. In order to reach this aim, healthcare providers must ensure that the linguistic, cognitive, and communicative-pragmatic values of the terms used are the same for the patients as they intended them to be. In other words, a healthcare provider must be attentive to the various connotations a patient can have while hearing a medical term. For example, when diagnosing or treating a patient's urinary infection, the healthcare provider must be very careful choosing the terms to talk about the patient's condition. First of all, based on the patient's linguacultural background, the 
clearest term should be chosen from urinary tract infection, UTI, bladder infection, urinary bladder infection, cystitis, problems with urination/peeing due to bacteria, etc. Secondly, it must be ensured that the patient understands the concepts covered by the term - e.g., while for a native speaker of English bladder infection may be enough to activate the relevant conceptual background, for a nonnative speaker, more explanation or simply another denomination would call the relevant concepts in mind. Furthermore, depending on the socio-cultural schemata of the patient, notions that relate to the genitalia, or when bodily fluids are simply taboos in a culture, or for certain groups in a society, naming the urinary bladder should be avoided at all, and rather more distant concepts should be aimed at, e.g., lower abdomen etc.

Based on the examples above, it is clear that choosing the right and appropriate medical terms in healthcare communication in an ELF context is not an easy task at all. It is with the help of terminological awareness that healthcare providers can explore the contextual features and choose the terms based on the informed assumptions about the interpersonal schemata shared with their patients. This involves a constant other-monitoring on the part of the healthcare provider, which leads to a raised awareness of the communicative processes, i.e. how the complex dynamic system of contextual features influence meaning formation on-line, and how to adjust language use to exploit these influences to the fullest in order to achieve effective communication with patients.

\section{RESEARCH QUESTIONS}

As it has been elaborated, in order for healthcare providers to select the most appropriate terminology in relation to the interpersonal schemata shared with their patients, it is necessary to constantly monitor the contextual features of the communicative situation they are engaged in. In line with this, the focus of the present research can be formulated as:
- What contextual features influence healthcare providers' language use while talking to foreign patients in English as a lingua franca?

- How do the various contextual features affect healthcare providers' language use?

\section{METHODOLOGY}

To find answer to the research questions listed in the previous section, the aim of the empirical part of the research is to collect data on what contextual features healthcare providers pay attention to when they are engaged in ELF communication with patients. Since these situations cannot be examined in real healthcare environment due to a range of ethical issues, e.g., the confidential communication with patients could be violated, the focus of inquiry is a series of retrospective interviews with Hungarian healthcare providers who have extended experience in communicating with patients in English in international environment. Although using this method implies that their approach to healthcare communication could not be compared to their actual language use, the ground based on what they make their decisions could more easily be explored, which is a key element in developing contextual and consequently terminological awareness on ESP classes.

\subsection{Participants}

Before conducting interviews, in the preparation phase, nine students attending the first year of a post-graduate program on English medical translation and interpreting, who are at the same time experienced healthcare professionals at various fields, were asked to collect the contextual features they pay attention to when engaging in healthcare communication either in English or in Hungarian. First they were given time to brainstorm in pairs, then their ideas were discussed with the whole group. The aim of this was to create a basis for forming the interview questions.

The approach to finding interviewees was to reach Hungarian healthcare professionals 
with as diverse experience in English healthcare communication as possible. Altogether five healthcare professionals have been interviewed, two men and three women. The first two healthcare providers were second year students in the medical translation and interpreting program of the faculty, and were interviewed together in order to provide input for each other and compare their experiences. One of them was an orthopaedic doctor, the other is a family doctor in training, both in their late twenties. The orthopaedic doctor has had various experiences in talking to patients in English in Spain and Italy, and also in her everyday practice in Hungary, while the family doctor took a three-month-long internship in his last year of study in the USA, where he met patients with various linguacultural backgrounds. The third participant, also an orthopaedic doctor was asked questions over the phone, and had worked in the UK on multiple occasions at private clinics and as a night-shift attending in hospitals. The next interview was also carried out on the phone with a pharmacist, who spent years in Norfolk, UK in a frequented pharmacy. The last interviewee worked as a medical hotline operator for foreign people in Hungary, and she also helped mediating between foreign patients and Hungarian healthcare providers.

\subsection{Instruments and data collection}

After formulating the first interview questions with the help of the group interview about contextual features, they were revised after each interview for wording or focus points in order to improve their efficiency. Semistructured interviews were conducted in Hungarian - being the mother tongue of the participants - about their work experience and their language use in healthcare settings where English was the language of communication. Although the exact questions raised were always modified according to the actual situation, the following structure was followed on each occasion:

- First the participants' work experience was mapped:
- Where did they work in an English speaking environment?

- For how long did they work there?

- Under what conditions did they work? What were the typical communicative situations they engaged in?

- Then the following questions were raised in relation to each major working situation they mentioned:

- What kind of patients did they mainly talk to? (nationality, age, socio-economic background etc.)

- How would you describe your language use in that situation? What did you find easy/difficult? (as opposed to Hungarian)

- When did you find your communication successful/unsuccessful? Why?

- What influenced your language use? How did you decide on how to talk to patients?

The interviews were recorded and transcribed for further analysis. Data analysis happened continuously during data collection, as the endpoint of data collection was determined in advance as the point where data is saturated enough, i.e. no more emerging themes come up, and the model seems detailed and coherent enough.

\subsection{Data analysis and results}

The analysis of the transcribed interview schedules was conducted with the help of the constant comparative method (Coffey \& Atkinson 1996; Maykut and Morehouse 1994; Strauss \& Corbin 1998). First, emerging categories have been collected, and by constantly compared to each other, the skeleton of contextual features perceived relevant in healthcare communication has been constructed. With the help of open and axial coding, categories could be built around three main notions: the characteristic features of patients and the environment influencing the communicative situation; the communicative challenge emerging from the contextual features that form ground for terminological choices; and the communicative strategies of healthcare providers to maintain efficiency.

For example, the pharmacist explained while talking about his experiences with non- 
native speakers of English that "if I could see that the patient is intelligent, and is from Eastern Europe, or Europe, belonging to the Latin culture, especially Southern Europeans, ... but I think Eastern Europeans too, ... they understood me better if I talked less in an English way, so to say in an everyday language, than if 1 talked in a Latinate way. (...) Furthermore, it happened quite often that used the words in both ways,... it doesn't cost a thing that I say both words at the same time... and I don't look down on her, so it's not a problem that she doesn't know what that word means exactly, rather... so that she can understand it. So she will understand one out of the two words." (pharmacist, II. 310-316, my translation).

As it can be seen, linguacultural background is mentioned as a main factor influencing the communicative challenges, and how these are addressed with special attention to language use. Additionally, the same pharmacist mentioned that in these cases where he met the largest number of non-native speakers of English (i.e. in the context of prescribing emergency hormonal contraception), most of the patients felt stressed or ashamed, at it further negatively influenced their language proficiency. The medical hotline operator added that "it is very difficult to know what counts as a sensitive issue in the country of the patient" (operator, II. 129-130, my translation), and therefore it is a must to carefully select the words to be used with foreign patients due to the differing sociocultural schemata. One of the orthopaedic doctors emphasised that "the amount of information patients understand, as far as I'm concerned, is not a matter of language, but rather a question how much one can process" (ortho2, II. 25-26, my translation) - this clearly shows that the cognitive schemata of one's interlocutor is a very important feature in creating the context. Furthermore, almost all of the interviewees referred to the importance of the immediate environment that affects the expectations towards the healthcare provider. For example, at private clinics, doctors are respected more, and are handled as "real professionals" (famdoc, I. 71, my translation), or as one of the orthopaedic doctors expressed it, in a private clinic environment, even healthcare providers spend more time with patients, and she even admitted that "I always ask back more. With Hungarian patients I never do it this precisely." (ortho1, II. 78-79). She underlined that even in Hungary she is more thorough and attentive to foreign patients, which results in slower tempo, more repetitions etc.

From the examples above, it can be seen that the picture is quite colourful, and that the list can never be full due to the richness of individual experiences, the dynamic nature of interpersonal schemata, and complexity of each situation. However, major clusters - or in other words umbrella categories can be explored among the contextual features, and by collating them with the communicative challenges they pose, propositions can be established as it is demonstrated in Table 1.

\begin{tabular}{ll}
\hline Contextual features & Communicative challenges \\
\hline $\begin{array}{l}\text { language (NS, NNS, accent, language use) } \\
\text { emotions (stress, shame) }\end{array}$ & $\begin{array}{l}\text { extent of vocabulary/terminology } \\
\text { altered language use }\end{array}$ \\
$\begin{array}{l}\text { environment (in person/ on the phone) } \\
\text { culture (boundaries, introducing themselves and } \\
\text { their problems, attitude towards the healthcare } \\
\text { provider, local habits) }\end{array}$ & $\begin{array}{l}\text { need for visual input } \\
\text { extent of information they share } \\
\text { much information they can absorb) }\end{array}$ \\
\begin{tabular}{l} 
social background (age, socio-economic status) \\
\hline
\end{tabular} & adjusting to patients' level \\
\hline
\end{tabular}

Table 1 Contextual features and the communicative challenges they pose 
As it could be spotted in the examples above, how healthcare providers respond to the communicative challenges has a direct effect on their language use. Such as providing doublets for medical concepts, or choosing terms that may not make the patient feel that the healthcare provider intrudes into his/her private sphere. However, it must be underlined that it is not assumed that any fixed proposition could be found on how certain contextual features should influence healthcare providers' language use. Rather, any empirical data collected in this area should focus on displaying the complex dynamic nature of healthcare communication.

\section{CONCLUSION}

For healthcare providers communication with patients in ELF is a very complex issue, being grounded on a set of assumptions. Still, in order to maximise the efficiency of any communicative situation, healthcare providers must take responsibility for making decisions informed by a thorough exploration of the context. However, in order to reach this efficiency, it is not enough for them to just explore the contextual features of each situation they engage in, but must possess a problem-solving capacity to adjust their language use to the features of the context that they perceive as relevant in the given situation, as a careful selection of terminology can save time in healthcare situations, where often people's lives are at stake. Therefore, ESP classes must focus on improving health science students' contextual awareness and on enabling them to develop a capacity to exploit the sources that can shape their language use such as the exploration of the context and their knowledge of medical terminology - in order to enhance the efficiency of their communication with patients in ELF.

\section{BIBLIOGRAPHY}

[1] de Beaugrande, R. (1980): Text, Discourse and Process. London: Longman.

[2] Cabré, M. T. [2003]: Theories of terminology: their description, prescription and explanation. Terminology, 9(2), 163-200.

[3] Coffey, A. - Atkinson, P. (1996): Making sense of qualitative data. London: Sage.

[4] Corrizzato, S. - Goracci, G. (2013): English for nursing: the importance of developing communicative competences. The Journal of Teaching English for Specific and Academic Purposes, 1(2), 177-184.

[5] Dörnyei Zoltán (2014): Researching complex dynamic systems: 'Retrodictive qualitative modelling' in the language classroom. Language Teaching, 47, pp 80-91.

[6] Dudley-Evans, T. - St John, M. J. (1998): Developments in English for Specific Purposes - A Multi-disciplinary Approach. Cambridge: Cambridge University Press.

[7] Eysenck, M. W. (2012): Fundamentals of cognition. Psychology Press.

[8] Faber, P. (editor) (2012): A cognitive linguistics view of terminology and specialized language. Berlin, Boston: De Gruyter Mouton.

[9] Firth, J. R. (1957): Papers in linguistics. 1934-1951. London: Oxford University Press.

[10] Fóris Á. (2012): Terminology and the theory of scale-free networks. Magyar Terminológia, 5(1), 58-71.

[11] Fóris Á. (2013): Network theory and terminology. Knowledge Organization, 40(6), 422429.

[12] Freedle, R. O. (editor) (1977): Discourse Production and Interpretation. Norwood, N.J.: Ablex.

[13] Frînculescu, I. C. (2009): The physiology of English as a lingua franca in medicine. Fiziologia - Physiology, 19(2), 4-6. 
[14] Grice, P. H. (1975): Logic and conversation. In P. Cole \& J. L. Morgan (Eds.), Syntax and semantics 3: speech acts, (pp. 41-58). New York: Academic Press.

[15] Hutchinson, T. - Waters, A. (1987): English for Specific Purposes. Cambridge: Cambridge University Press.

[16] Hymes, D. H. (1968): The ethnography of speaking. In J. J. Fishman (Ed.), Readings in the Sociology of Language. The Hague: Mouton.

[17] Hymes, D. H. (1974): Foundations of Sociolinguistics. Pittsburgh: University of Pennsylvania Press.

[18] Illés Éva (2012): Approaches to context. In S. Kleinke, Z. Kövecses, A. Musolff \& V. Szelid (Eds.), Cognition and culture, (pp. 19-27). Budapest: ELTE Eötvös Kiadó.

[19] Larsen-Freeman, D. (2012): Complex, dynamic systems: A new transdisciplinary theme for applied linguistics? Language Teaching, 45(2), 202-214.

[20] Malinowski, B. (1923): The problem of meaning in primitive languages. Appendix to C. K. Ogden and I. A. Richards, The Meaning of Meaning. London: Routledge \& Kegan Paul.

[21] Maykut, P. - Morehouse, R. (1994): Beginning qualitative research: A philosophic and practical guide. London: Routledge Falmer.

[22] Mey, J. (1993): Pragmatics: An Introduction. Oxford: Blackwell.

[23] Pilegaard, M. (1997): Translation of medical research articles. In A. Trosborg (Ed.), Text typology and translation (pp. 159-183). Amsterdam, Philadelphia: John Benjamins.

[24] Pilling János (2011): Medical communication. Budapest: Medicina Könyvkiadó.

[25] Ruiz Rosendo, L. (2008): English and Spanish medical languages: A comparative study from a translation point of view. Trans: Revista de Traductologia, 12, 231-246.

[26] Seidlhofer, B. (2011): Understanding English as a lingua franca. Oxford: Oxford University Press.

[27] Sperber, D. - Wilson, D. (1995): Relevance: Communication and Cognition. $2^{\text {nd }}$ edn. Oxford: Blackwell.

[28] Strauss, A. - Corbin, J. (1998): Basics of qualitative research: techniques and procedures for developing grounded theory. Thousand Oaks, CA: Sage Publications.

[29] Van de Poel, K. - Vanagt, E. - Schrimpf, U. - Gasiorek, J. (2013): Communication Skills for Foreign and Mobile Medical Professionals. Springer.

[30] Widdowson, H. G. (1983): Language Purpose and Language Use. Oxford: Oxford University Press.

[31] Widdowson, H. G. (2004): Text, context, pretext. Oxford: Blackwell Publishing.

[32] Widdowson, H. G. (2007): Discourse analysis. Oxford: Oxford University Press. 